\title{
Os cantores do rádio que protagonizaram filmes da Atlântida
}

\author{
SANDRA CIOCCI \\ NEY CARRASCO**
}

\begin{abstract}
RESUMO: As produções da Companhia Atlântida Cinematográfica tiveram muitas canções inseridas, em formato de número musical. A presença dos cantores do rádio, nesses números musicais, era determinada pela exigência do público que desejava conhecer os ídolos do rádio, dos quais conhecia apenas a voz. Este artigo trata da transformação da função dos cantores para cantores/atores e das canções, por eles interpretadas, nos filmes da Atlântida durante duas décadas de produção.
\end{abstract}

PALAVRAS-CHAVE: filme musical, trilha musical, música popular, Atlântida, rádio popular.

\section{The radio singers who staged films of Atlântida}

\begin{abstract}
The productions made by Companhia Atlântida Cinematográfica placed several songs in musical number format. The presence of the radio singers in these musical numbers was determined by the public's demands, who wished to know the radio idols, of whom they only knew the voice. This article deals with the transformation in the singers' function to sing/actor and songs interpreted by them in Atlântida's productions, during two decades.

KEYWORDS: musical film, sound score, popular music, Atlântida, popular radio.
\end{abstract}

\footnotetext{
* Sandra Ciocci é graduada em Música Popular - UNICAMP (1992), mestre em música - UNICAMP (2010), doutoranda em Música - UNICAMP e Membro do grupo de música e sound design aplicados à dramaturgia e ao audiovisual, no departamento de música do instituto de artes - UNICAMP. Tem como área central de pesquisa a trilha musical do cinema brasileiro. E-mail: sandraciocci@gmail.com ** Ney Carrasco possui graduação em Música - Composição pela Universidade Estadual de Campinas (1987), mestrado em Cinema pela Universidade de São Paulo (1993) e doutorado em Cinema pela Universidade de São Paulo (1998). Atua como compositor de trilhas musicais para teatro, cinema de animação e televisão desde 1985. É professor do Departamento de Música da Universidade Estadual de Campinas desde 1989 e atua nos programas de pós-graduação (mestrado e doutorado) em Música e em Multimeios pela mesma universidade desde 1999. Desde 2006 coordena o Grupo de Pesquisa em Música Aplicada à Dramaturgia e ao Audiovisual, registrado no CNPq e sediado no Instituto de Artes da UNICAMP. Atua também nas áreas de Música Popular e Tecnologia Aplicada à Música. É pesquisador $\mathrm{CNPq}$ nível $1 \mathrm{~d}$ e atualmente ocupa o cargo de secretário municipal de cultura de Campinas - SP. E-mail: carrasco@iar.unicamp.br
} 
Companhia Atlântida Cinematográfica foi uma empresa brasileira de
produção de filmes, fundada em 1941 por Moacyr Fenelon ${ }^{1}$ e José Carlos
Burle $^{2}$. Segundo relatos de Burle, Fenelon o teria encontrado em Copacabana, na rua, e lhe oferecido ações para a incorporação da produtora Atlântida Cinematográfica, da qual ele, Fenelon, era diretor técnico e artístico. Burle não apenas comprou ações como as vendeu a amigos como o Conde Pereira Carneiro e a seu próprio irmão, Paulo Burle (BARRO, 2007, p. 83-94).

O empenho de Burle e Fenelon trouxe para a Atlântida acionistas como Rachel de Queiroz, Eleazar de Carvalho, Cândido Portinari e Manuel de Teffé (BARRO, 2007, p. 100). Muitas pessoas acreditavam no sucesso da empresa, pois o então presidente Getúlio Vargas havia assinado, em dezembro de 1939, uma lei que estipulava a quantidade de filmes brasileiros que deveriam ser apresentados nas salas de exibição do país, além do decreto que obrigava a exibição de um jornal cinematográfico brasileiro em todas as sessões. Como não havia muitas empresas no ramo, os filmes produzidos teriam exibição garantida.

Embora Burle e Fenelon tivessem como objetivo produzir filmes longa metragem de ficção e almejassem lançar filmes que "valorizassem nossos temas, no que possuímos de mais belo, nos ambientes pictóricos e regionais, nos aspectos sociais do homem brasileiro, na sua história, na sua arte, suas tradições e seus costumes e na psicologia desse homem"3, ainda nos primeiros anos de funcionamento da companhia perceberam a necessidade financeira de produzir filmes de apelo popular.

O modelo de filme adotado pela Atlântida para arrebanhar público para as salas de exibição foi a comédia musical. Este modelo não foi criado pela Atlântida, mas foi por ela aperfeiçoado e usado à exaustão. A partir do momento em que os

\footnotetext{
${ }^{1}$ Moacyr Fenelon de Miranda Henriques (1903-1953). Natural de Patrocínio do Muriaé. Aproximou-se de Luiz de Barros, durante período que trabalhou na instalação de rádios para a Columbia, capitaneada por Alberto Byington Jr. Segundo depoimento de Fenelon para a revista Cena muda, ele teria trabalhado com Luiz de Barros em Acabaram-se os otários (1929) como sonografista e aí iniciado sua carreira no cinema, fato que Luiz de Barros não confirma (RAMOS e MIRANDA, 2004)

${ }^{2}$ José Carlos Queiroz Burle (1910-1983). Natural do Recife. Médico. Aprendeu piano na adolescência. Atuou como jornalista escrevendo crônicas para o Jornal do Brasil durante o ano de 1936, tendo passado a redator em 1937, cargo que ocupou até 1942.

3 Trecho retirado da carta manifesto, redigida no estabelecimento da Atlântida e entregue aos acionistas.
} 
sócios Burle e Fenelon perceberam que uma comédia era capaz de cobrir as despesas de produção, trazer lucros e financiar outras produções, utilizaram-na à exaustão.

A primeira comédia musical produzida pela Atlântida foi Tristezas não pagam dívidas (1944), filme que tinha na trilha musical canções interpretadas por Silvio Caldas, Quatro Ases e Um Coringa, Zilah Fonseca, Joel e Gaúcho, Blecaute, Marion, Dircinha Batista e Emilinha Borba. O formato desse filme foi claramente imposto pelo equipamento de gravação que a empresa possuía, ou melhor, pelo equipamento que ela não possuía. Segundo Máximo Barro, Fenelon usava uma câmera comprada de segunda mão, originalmente muda, com adaptação de um sistema sonoro primitivo, que gravava simultaneamente, no mesmo negativo, som e imagem (BARRO, 2007, p. 102). Assim, era impossível fazer edição do som, que só podia ser captado no sistema de som direto.

A incapacidade de edição de som impôs a separação entre os elementos componentes da trilha sonora ${ }^{4}$, isto é, quando havia diálogos não era possível inserir música, quando havia música não havia diálogo e ruídos de sala eram praticamente inexistentes, nas primeiras produções da Atlântida.

Por esse motivo, os filmes da empresa tiveram números musicais inseridos como nos primeiros anos do cinema sonoro de Hollywood, isto é, os quadros musicais eram justificados na narrativa para que houvesse uma explicação para a presença de músicos e cantores, embora esse procedimento já não fosse mais considerado necessário no cinema norte-americano havia quase uma década. Utilizando como exemplo o já citado Tristezas não pagam dívidas, podemos constatar que as personagens são levadas, no decorrer da narrativa, a uma gafieira onde são apresentadas as canções interpretadas por Zilah Fonseca e Blecaute. Em outro momento são transportadas a uma estação de rádio onde encontramos Joel e Gaúcho e Linda Batista, com direito a locução, explicando quem é o cantor e qual o nome da canção que interpretaria. Em um terceiro momento as personagens vão a um cassino e assistem Emilinha Borba, Marion e Ataulfo Alves. A única inserção de número musical nesse filme, fora de ambientes de lazer, é feita em um número com Oscarito

\footnotetext{
${ }^{4}$ A definição dos elementos formadores da trilha sonora de uma produção audiovisual é, aqui, utilizada conforme descritos em Carrasco (1993).
} 
e o grupo Quatro Ases e Um Coringa, que é ambientado em uma aula de música dentro de um hospital psiquiátrico, logo no inicio do filme.

Nos filmes musicais da Atlântida podemos encontrar os números musicais inseridos de três maneiras:

- Número de condução - a letra da canção ocupa o lugar do diálogo e participa da progressão dramático-narrativa.

- Número de adição - a letra da canção não está no lugar dos diálogos, mas existe algum tipo de informação adicionada à progressão dramático-narrativa, como, por exemplo, a apresentação de uma personagem, localização temporal ou localização geográfica.

- Número de ruptura - não existe nenhum avanço da progressão dramática, isto é, o número provoca um rompimento na progressão dramático-narrativa e ela é retomada ao final do número.

Nos primeiros filmes musicais da Atlântida, raramente são encontrados números de condução da progressão dramático-narrativa. As canções eram sempre justificadas de uma maneira que, se fossem retiradas, modificariam o filme, mas sem afetar a progressão dramático-narrativa. Esse procedimento se repetia cada vez com mais frequência dentro dos filmes da Atlântida e de outras companhias contemporâneas a ela, como, por exemplo, a Cinédia. Voltando ao exemplo de Tristezas não pagam dívidas, apenas a primeira canção agrega informações à narrativa, como a apresentação da personagem Carlinhos (Oscarito); as demais são números musicais que provocam a ruptura da progressão dramático-narrativa, tal como ocorreu em diversos momentos com a ária ao longo da história da ópera.

Essa ruptura pode parecer uma precariedade na estrutura do filme. Outra suposição era que o público se entediava com as interferências e que não gostava das comédias populares brasileiras. Nenhuma dessas hipóteses é correta. Essa é a convenção poética do musical popular brasileiro e foi aceita pelo público que lotava as salas para assistir às comédias musicais da Atlântida, mesmo contrariando a crítica que se opunha ao modelo. O sucesso das comédias da Atlântida chegou a levar para 
as salas de exibição, em 1959, 15 milhões de espectadores durante as exibições de $O$ homem do Sputnik 5 .

Os números musicais tiveram diversos elementos trazidos do Teatro de Revista, que era consagrado pelo público brasileiro havia algumas décadas. Alguns desses números foram transportados na forma original, das Revistas nas quais a narrativa é apenas um fio condutor, um pretexto para forjar a ligação entre os números, característica dos espetáculos de variedades. Na Revista a narrativa era interrompida por uma média de 15 a 20 quadros. A revista abria com uma ouverture orquestrada, seguida do prólogo, e tinha um corpo formado pela alternância de cortina, quadro de comédia, quadro de fantasia e o quadro de vedete ou de plateia, não necessariamente nessa ordem, até a apoteose (VENEZIANO, 1991, p. 92 e 93).

O prólogo era o número de abertura. Os números de cortina, no teatro, aconteciam diante de uma cortina mais leve que o pano de boca e que fechava completamente o palco. O pano de boca era utilizado apenas no início e no fim da Revista e os números de cortina existiam, portanto, exatamente para encher o tempo. Poderia aparecer um cantor ou uma cantora, um cançonetista ou mesmo um cômico e caipiradas, dupla caipira. Enquanto eles eram realizados na frente da cortina, toda movimentação de troca de cenário, por exemplo, acontecia no palco (VENEZIANO, 1991, p. 99 e 100). Os números de fantasia eram quadros em que o luxo, a iluminação, os figurinos e a cenografia imperavam a fim de pôr em destaque grandes números musicais e contavam com belas mulheres, girls, ou homens, boys, visual colorido e música vibrante. As fantasias eram quadros desarticulados do fio condutor, completamente estranhos ao assunto narrado. A música desses números, embora com melodias simples, recebia arranjo de importantes maestros oriundos da ópera (VENEZIANO, 1991, p. 105 e 106). O quadro de vedete é explicado pelo próprio nome: nele aparecia a vedete, a estrela da companhia, o momento mais esperado da revista.

Ao analisar os quadros de Tristezas não pagam dívidas, verificamos que as canções interpretadas por Emilinha Borba e Joel e Gaúcho ocorrem diante de cortinas

\footnotetext{
${ }^{5}$ Dados obtidos nos arquivos da família Severiano Ribeiro com autorização do senhor Luis Henrique Severiano Ribeiro Baez.
} 
ligeiras, como os números de cortina, embora no cinema não houvesse a necessidade de preencher o tempo para troca de cenário. Os números musicais com as canções na voz de Dircinha Batista, Silvio Caldas e Marion podem ser classificados como quadro de fantasias. Dircinha interpreta a canção "Clube dos barrigudos" no próprio clube, com mesas, sócios e pista de dança. A canção "Laura", na voz de Silvio Caldas nos leva a uma favela repleta de barracos, músicos e bananeiras. O número com Marion, embora muito deteriorado pela má conservação da fita, nos permite reconhecer que o cenário é um bar com vários marinheiros.

Os números musicais foram trazidos das Revistas de ano, mas a escolha dos intérpretes ocorreu por influência da indústria cultural que se estabelecia no Brasil. Segundo Lia Calabre, o rádio popular criou uma corte imaginária com rainhas e reis da voz, sempre seguidos por súditos fiéis. Os ouvintes mais assíduos e apaixonados desejavam saber que aparência tinham os cantores e cantoras, o que vestiam, o que consumiam e como moravam seus astros prediletos. Filas se formavam à porta das rádios na tentativa de uma aproximação, de um toque, de um autógrafo. Em pouco tempo, os diretores das rádios perceberam que o ambiente apertado dos estúdios não comportava a quantidade de fãs que iam às emissoras diariamente e passaram a construir grandes espaços, em forma de auditórios, para realizar os programas com a presença de ouvintes, mas esse espaço tornou-se pequeno também. Não era possível colocar dentro das rádios todos que queriam conhecer de perto seus cantores favoritos. Além da falta de espaço, havia ainda o problema da localização das emissoras, distantes das cidades do interior do país. Iniciou-se a produção de publicações especializadas em levar essas informações ao público. Porém, nas publicações os astros e as estrelas estavam estáticos. Continuava a curiosidade de conhecer cada gesto e movimento de seus ídolos, bem como as peculiaridades de suas performances (CALABRE, 2002, p. 38-41). Se o rádio divulgava e promovia as vozes, o cinema lhes dava rostos, gestos, olhares, material suficiente para enlouquecer até os súditos mais exigentes.

Com a chegada de tecnologia à Atlântida, a música pôde ser inserida de outras formas, além dos números musicais, nos filmes produzidos por esta empresa. Nos musicais carnavalescos o formato se manteve devido à necessidade de 
apresentar as canções de carnaval para o público. Esses filmes eram, geralmente, produzidos do fim de novembro até meados de dezembro e exibido a partir da primeira semana de janeiro, para que, dessa forma, mostrassem ao público as músicas de carnaval que tocariam nos bailes em fevereiro. Nas demais produções da empresa, como os filmes policiais e dramas, aparece uma conscientização, por parte dos diretores, da utilização mais comedida das canções. Após algumas experiências com os novos aportes tecnológicos e a mudança de profissionais, os números musicais passaram a ter uma ligação maior com a narrativa e tornaram-se portadores de elementos da progressão dramático-narrativa.

$\mathrm{Na}$ busca por uma ligação dos números musicais com a progressão dramático-narrativa, os diretores passaram a produzir os quadros com os protagonistas dos filmes. Alguns atores como Oscarito, Eliana Macedo e Grande Otelo se adaptaram à situação e, mesmo não sendo músicos, conseguiram cantar em diversos filmes sem comprometer a qualidade das produções. Muitos números musicais de Oscarito nos filmes da Atlântida foram consagrados, mas nem todos os atores foram capazes de assimilar o canto, como, por exemplo, John Herbert, que em Matar ou correr (1954) foi dublado pelo cantor Anísio Silva na canção "Ninguém para amar", de autoria do próprio Anísio Silva. Outro exemplo foi Cyl Farney, que em Chico Viola não morreu (1955) gravou todos os números musicais em forma de playback com gravações preexistentes de Francisco Alves.

Como saída para esse problema, o recurso utilizado pelos diretores foi transformar os consagrados cantores do rádio em protagonistas que foram ocupando o espaço dos atores vindos do teatro. Devemos nos lembrar de que nessa época não havia uma escola específica para formar profissionais de cinema em nenhuma das áreas. E como o cinema não é um teatro em registro audiovisual, era preciso ensinar aos profissionais a atuarem diante das câmeras. Se partirmos do pressuposto que alguém teria que ser instruído, não importava a origem desse profissional, se do rádio ou do teatro. O que parece mais provável é que, como as canções tinham um lugar de destaque nas produções, era pré-requisito que o protagonista cantasse. Se o ator não conseguia se adaptar ao canto, ele perdia seu lugar para o cantor que conseguisse atuar. 
A sequência deste artigo trata dos cantores que conseguiram fazer a ponte entre a participação em números musicais e a atuação como protagonista.

\section{As rainhas do rádio nas telas do cinema}

O primeiro concurso de rainha do rádio "foi promovido em 1936 pelo jornal Diário da Noite e por um bloco carnavalesco, o Cordão das Laranjas. Prolongouse até as vésperas do carnaval de 1937", meia década antes da fundação da Atlântida. A primeira rainha do rádio foi Linda Batista. Na primeira fase do concurso a rainha era eleita pelo voto "de artistas, jornalistas, críticos, gente do meio radiofônico" (HUPFER, 2009, p. 24). Assim como o rádio daquela época, o concurso era regionalizado 6 e não tinha repercussão fora do estado do Rio de Janeiro. Adelaide Chiozzo $^{7}$, em depoimento, nos informou que a partir de 1948 o concurso passou a ser organizado pela Associação Brasileira de Rádio (ABR). A forma de obter os votos passou a ser a venda de cada voto por um cruzeiro. Esse dinheiro, segundo Adelaide, era utilizado na construção de um hospital para os artistas e funcionários das rádios. Os votos eram vendidos a fãs e a patrocinadores. Os patrocinadores, donos de empresas anunciantes no rádio popular, investiam o dinheiro em sua candidata, na intenção que esta fosse vencedora e atuasse como garota propaganda de seus produtos, em um futuro próximo.

"A lisura dos concursos era contestada com frequência, já que as manobras de bastidores nem sempre eram feitas com a ética esperada" (HUPFER, 2009, p. 25). Adelaide Chiozzo nos afirmou que no ano em que foi candidata perdeu o concurso no último instante. Ela se encontrava como primeira colocada há dias, mas com uma pequena vantagem sobre a da segunda colocada. Uma terceira candidata teria retirado a candidatura no último instante e doado seus (poucos) votos para a segunda candidata, que ultrapassou Adelaide e ficou com o título, pois

\footnotetext{
${ }^{6}$ As rádios do início da década de 30 tinham a potência capaz de levar a programação por no máximo $250 \mathrm{~km}$, o que impossibilitava que rádios de um estado retransmitissem para outro.

7 As informações de Adelaide Chiozzo, aqui citadas, foram concedidas pela cantora em entrevista pessoal para esta pesquisa, com apoio da Rede Globo de Televisão, através do programa Globo Universidades.
} 
no momento que se firmou tal acordo entre suas duas rivais não havia tempo hábil para Adelaide investir, nem mesmo seu próprio dinheiro.

Esses acontecimentos aqueciam as disputas entre os fãs-clubes e, de certo modo, ajudavam a impulsionar a comunicação de massa no Brasil, que ocupava um espaço importante no cotidiano de muitas pessoas. "Pode-se dizer que os concursos de Rainha do Rádio azeitavam ou lubrificavam as engrenagens da indústria cultural, especialmente numa época do ano em que ela funcionava a todo vapor, ou seja, nos meses que antecediam ao carnaval" (HUPFER, 2009, p. 25).

A Atlântida percebeu a eficácia do produto "musical de carnaval". Além de utilizar a fórmula rentável nos meses que antecediam o carnaval, passou a empregar o formato do musical em produções que estavam ligadas a outras festas populares, em diferentes meses do ano, como as festas de junho. O público lotava as salas de exibição em busca dos rostos que compunham, com tão conhecida voz, a imagem de seus ídolos.

A primeira produção da Atlântida foi um documentário sobre o Congresso Eucarístico Nacional, em maio de 1942. Para que a produção fosse considerada longa-metragem, foi produzida uma seleção de quadros musicais sob o nome: Astros em desfile. Essa produção era exibida juntamente com o documentário. Segundo dados dos arquivos da Cinemateca Brasileira, em São Paulo, Emilinha Borba teria participado da produção, da qual também tomaram parte Luiz Gonzaga, Cyro Monteiro, Manezinho Araújo e Quatro Ases e Um Coringa. Esse fato nos aponta que a análise unilateral, afirmando que as rainhas do rádio iam para as telas do cinema para promover o filme, carece de maior fundamento. As cantoras do rádio apareciam nos filmes também em busca de espaço para divulgar seus trabalhos e chegar a ocupar o posto de rainha do rádio. Nesse contexto as rádios cediam os cantores consagrados para participar dos filmes e levar público às salas de exibição, mas buscavam igualmente aproveitar a presença desse público e lançavam cantores novatos.

Além dos aspectos anteriormente citados, a parceria com o rádio foi feita por causa da falta de estrutura para gravação da trilha musical nos estúdios da Atlântida. Na companhia, assim como em outras empresas de cinema, no Brasil, não 
existia um estúdio capaz de comportar um grupo de músicos para produzir a trilha musical dos filmes, como se fazia em Hollywood. A primeira empresa cinematográfica que construiu um estúdio para gravação de trilhas, no molde hollywoodiano, foi a Vera Cruz, em São Paulo, na década de 50. O que existiu entre a Atlântida e as rádios foi um acordo de cavalheiros: a rádio cedia o espaço que a Atlântida precisava para gravar as trilhas musicais e esta promovia os artistas da emissora de rádio. Encontramos informações em arquivos da companhia e em créditos de filmes que comprovam as parcerias entre a Atlântida e as rádios Nacional e Tupi.

Até o presente momento esta pesquisa confirmou a presença, nas comédias musicais da Atlântida, das seguintes Rainhas do Rádio:

\begin{tabular}{|c|c|c|}
\hline Rainha do rádio & Ano que foi eleita & Filmes da Atlântida em que atuou \\
\hline Linda Batista & 1937 a 19478 & $\begin{array}{l}\text { Tristezas não pagam dívidas (1944) } \\
\text { Não adianta chorar (1945) }\end{array}$ \\
\hline Dircinha Batista & 1948 & $\begin{array}{l}\text { Não adianta chorar (1945) } \\
\text { Guerra ao samba (1955) }\end{array}$ \\
\hline Marlene & 1949 & \\
\hline $\begin{array}{ll}\text { Dalva } & \text { de } \\
\text { Oliveira } & \end{array}$ & 1951 & \\
\hline Mary Gonçalves & 1952 & Barnabé tu és meu (1952) \\
\hline Emilinha Borba & 1953 & $\begin{array}{l}\text { Astros em desfile (1942) } \\
\text { Tristezas não pagam dívidas (1944) } \\
\text { Não adianta chorar (1945) } \\
\text { É com esse que eu vou (1948) } \\
\text { Aviso aos navegantes (1951) } \\
\text { Barnabé tu és meu (1952) } \\
\text { Vamos com calma (1955) } \\
\text { Garotas e Samba (1957) }\end{array}$ \\
\hline Ângela Maria & 1954 & \\
\hline Vera Lúcia & 1955 & \\
\hline Dóris Monteiro & 1956 & $\begin{array}{l}\text { De vento em popa }(1957) \\
\text { E o espetáculo continua }(1958)\end{array}$ \\
\hline
\end{tabular}

Percebemos que Marlene, Dalva de Oliveira, Ângela Maria e Vera Lúcia não atuaram nas comédias musicais produzidas pela Atlântida, mas, segundo Hupfer, estiveram em produções de outras companhias. As rainhas do rádio Linda Batista, Dircinha Batista e Mary Gonçalves tiveram canções inseridas em formato de número musical nas comédias da Atlântida, mas não existia uma personagem para

\footnotetext{
${ }^{8}$ No ano de 1947, Linda abdicou para favorecer a irmã Dircinha Batista.
} 
elas. Elas representavam a si mesmas cantando suas canções em rádios, bailes ou shows, dentro da progressão dramático-narrativa.

Seguiremos então, nosso trabalho com as cantoras que, além de números musicais, protagonizaram produções da Atlântida: Emilinha Borba, Dóris Monteiro e Adelaide Chiozzo, embora Adelaide não tenha sido, efetivamente, uma rainha do rádio.

\section{Emilinha Borba nas produções da Atlântida}

A cantora Emilinha Borba, intitulada a "Favorita da Marinha", foi a campeã em participações nos filmes musicais brasileiros e também da Companhia Atlântida. Segundo Hupfer, Emilinha participou de 27 filmes de longa metragem, 11 na Atlântida (HUPFER, 2009, p. 166).

Emilinha começou a participar de filmes em 1941 e foi eleita rainha do rádio em 1953. Este fato indica que o título "apenas veio confirmar sua popularidade, não significando necessariamente abertura de espaço no cinema da época" (HUPFER, 2009, p. 162).

Em Tristezas não pagam dívidas (1944), seu primeiro filme na Atlântida, a cantora interpretou "Atire a primeira pedra", de Ataulfo Alves e Mario Lago em um ambiente dentro de um cassino. $\mathrm{O}$ trecho remete aos números de cortina do teatro de revista, sendo produzido, integralmente, na frente de uma cortina leve, em companhia de casais que cantavam o refrão da canção com a cantora. Não há informação adicionada à narrativa ou apresentação de personagem e a letra não se encontra no lugar dos diálogos. Qualquer outra canção poderia ter sido utilizada para o número, mas "Atire a primeira" pedra foi a escolhida e foi considerada uma das seis gravações mais representativas para o mercado fonográfico brasileiro em 1944, segundo o livro A canção no tempo (SEVERIANO e MELLO, 1997, p. 225). Percebemos que não existe a presença de músicos nesse número musical, pois nos filmes da Atlântida não havia preocupação em apresentar o aparato musical. Isto é, não existe a necessidade de que o público faça uma leitura realista, mas existe a busca 
por uma justificação da existência de canções e de cantores na progressão dramáticonarrativa.

Em 1948, Emilinha participou de É com esse que eu vou. Nessa produção ela teve participação em um quadro musical ambientado em uma boate. A canção utilizada para o dueto com Ruy Rey foi “Tico-tico na rumba”, de Peterpan e Haroldo Barbosa, por sinal um dos sucessos de 1948 (SEVERIANO e MELLO, 1997, p. 256). O número musical faz a ruptura da progressão dramático-narrativa, interrompe um diálogo entre o protagonista e a vilã. Os diálogos são separados pela canção, mas a conversa tem continuidade, como se o casal parasse a discussão para ouvir uma música que era tocada na boate e depois retomasse a conversa do mesmo ponto em que havia parado.

No filme Aviso aos navegantes (1950), Emilinha teve um quadro com a canção "Tomara que chova", de autoria de Paquito e Romeu Gentil. O número faz parte de um show dentro do navio onde se desenvolve a narrativa. A canção é listada entre as 30 mais executadas em 1951 (SEVERIANO e MELLO, 1997, p. 286), mas, como a lista foi feita por ordem alfabética, é impossível assegurar o nível de popularidade dessa marcha naquele ano. A letra da canção, totalmente deslocada da narrativa, fala sobre a falta de água que aterrorizava a população carioca da época. Era prática comum, nas comédias da Atlântida, colocar um problema da sociedade carioca ou brasileira de maneira jocosa.

Em Barnabé tu és meu (1952), Emilinha forma um dos dois pares românticos do filme. A canção "Fora do Samba" de Amadeu Veloso, Peterpan e Paulo Gesta, é utilizada para compor um número ambientado em uma boate. Este número apresenta a personagem Rosita (Emilinha), uma cantora que fará par romântico com Carlos (Cyl Farney), um espião da polícia, infiltrado na boate para descobrir a identidade de um vilão. Emilinha volta ao palco da boate, aos cinquenta e sete minutos do filme, com "Mucho gusto", de autoria de Ruy Rey, que participa do quadro com a orquestra que leva o nome dele. Este número também foi produzido utilizando uma boate como cenário. Em Barnabé tu és meu, Emilinha tem uma personagem; ela deixa de ser a cantora e passa a fazer parte da progressão dramáticonarrativa. Essa personagem é uma cantora oprimida pelo vilão e que ao final 
consegue se libertar, com a ajuda de Carlos. Essa comédia é a única, na Atlântida, que Emilinha protagonizou. As demais participações foram em números musicais desligados da progressão dramático-narrativa.

Em Vamos com calma (1956) Emilinha interpretou "Pescador granfino", composição de João de Barro, uma das 22 canções que compõem os 120 minutos de filme. Cabe aqui abrir espaço para refletir sobre a importância da canção no musical popular da Atlântida. Se pensarmos que cada canção pode ter em média três minutos, as 22 totalizariam mais de 60 minutos de música na forma de canção, em um único filme. Estas representam 50\% da duração do filme, aproximadamente, enquanto a soma entre a exibição dos créditos iniciais, a exposição do mote, o desenvolvimento e a conclusão da progressão dramático-narrativa dividem os outros 50\%. Retomando a explicação sobre o número musical de Emilinha em Vamos com calma, a canção faz parte do ensaio de um show que será promovido pelas personagens. A exposição de "Pescador granfino", uma marcha de carnaval, não apresenta elementos novos. Tal composição teve uma concorrente poderosa no carnaval daquele ano, "Quem sabe, sabe”, de Joel de Almeida. Por esse motivo não obteve muito reconhecimento popular.

A participação de Emilinha em Garotas e samba (1957) pode ser confirmada pelo documentário Assim era a Atlântida (1974), mas envolve um dos capítulos mais tristes sobre a história da conservação do acervo da Atlântida. Com objetivo de aproveitar o material produzido pela Atlântida durante duas décadas, os detentores dos direitos do acervo contrataram profissionais para realizar o documentário. A iniciativa era válida: retomar a história de uma das mais produtivas companhias de cinema brasileira. O problema surgiu no momento da produção, quando foram mutilados os originais. Alguns números musicais e diversos trechos da narrativa foram retirados dos filmes para compor o documentário. Esses trechos nunca mais foram devolvidos aos lugares de origem. Sabemos que a canção na voz de Emilinha está no filme, mas não podemos analisar a função do número musical, pois não sabemos exatamente em que ponto da narrativa ele foi inserido. Pelo resultado das nossas pesquisas podemos sugerir que o quadro tenha sido retirado da sequência dentro da boate onde atua a vedete Zizi (Sonia Mamed). Segundo depoimentos de 
Manga, Emilinha deveria ter gravado um segundo número musical para essa comédia com a canção "Vai com jeito" de João de Barro. Ele nos explicou que a canção tinha sido gravada para o carnaval por Emilinha, mas que o número foi modificado, passando a canção para Sonia Mamed. Sonia interpretava a vedete Zizi, e o uso da canção na voz de Sonia trazia a afirmação das qualidades da personagem como artista.

\section{Adelaide Chiozzo nas produções da Atlântida}

Adelaide não venceu o concurso para rainha do rádio, como dissemos anteriormente, mas foi de tal forma atuante na Atlântida que o nome da cantora passou a compor os créditos dos atores, como veremos a seguir.

A primeira aparição de Adelaide Chiozzo nas telas do cinema foi como figurante em uma cena estrelada por Bob Nelson em Este mundo é um pandeiro (1946), da Atlântida. Segundo Adelaide, ela tocou acordeom, sentada, em um canto do cenário. A única ordem que recebeu do diretor foi que sorrisse o tempo todo. Adelaide obedeceu e foi convidada para a produção de É com este que eu vou (1948). Neste filme, a dupla Irmãos $\mathrm{Chiozzo}^{9}$ aparece nos créditos por acompanhar o cantor Bob Nelson em "Como é burro o meu cavalo". Constatamos aqui como os números musicais costumavam interromper por completo a narrativa, pois esse trecho do filme foi produzido com uma canção que falava sobre um cavalo, a ambientação era uma fazenda e o filme se passa no Rio de Janeiro, isto é, não há nenhuma conexão entre uma coisa e outra. A justificativa utilizada para apresentar a canção é que as personagens estão ensaiando um show no jardim de uma mansão carioca, onde o cenário jamais seria uma fazenda. Dessa maneira, percebemos que os diretores se preocupavam em justificar a presença dos músicos, mas não viam a necessidade manter uma construção realista.

\footnotetext{
${ }_{9}^{9}$ Adelaide nos explicou que quando foi convidada, pela primeira vez, para trabalhar no rádio, seu pai, um italiano de costumes severos, colocou uma condição para aprovar a carreira de cantora, que não era bem vista pela sociedade daquela época. Adelaide deveria ensinar o irmão a tocar acordeom para que trabalhassem em dupla, assegurando, assim, que ela não "ficasse falada" pela sociedade. Adelaide seguiu as ordens do pai, ensinou o irmão e formou a dupla Irmãos Chiozzo.
} 
O primeiro trabalho de Adelaide não existe mais porque o filme foi queimado durante um incêndio em 1947, nos estúdios da Atlântida, mas o segundo encontra-se na Cinemateca Brasileira, em condições de visualização por pesquisadores.

O irmão de Adelaide decidiu se casar após a gravação de É com este que eu vou, e na produção seguinte, E o mundo se diverte (1948), Adelaide participou do filme como protagonista de um quadro com a canção "Tempo de criança". Este é justificado por ensaios para uma Revista que as personagens estão montando. A inserção acontece após uma hora e vinte e dois minutos de filme. Ao final, no mesmo cenário foi inserida outra canção, interpretada por Luiz Gonzaga que também canta acompanhado do próprio acordeom. Adelaide nos informou que "Tempo de criança" foi gravada por ela, depois de Emilinha Borba a ter rejeitado. O compositor Ely Turquini teria procurado a cantora, na Rádio Nacional, mas ela não simpatizara com a composição e teria apresentado Adelaide ao compositor, que lhe ofereceu a música.

Em 1949, Adelaide participou de Carnaval no fogo e, embora a cantora execute o choro "Tico-tico no fubá", de Zequinha de Abreu, ela conquistou lugar entre os créditos de atores, por iniciar parceria com Eliana Macedo. Nesse filme, Adelaide tem algumas poucas falas, mas diversas cenas. Estaria, também, neste filme "Pedalando", de Anselmo Duarte e Bené Nunes, mas esse quadro se encontra nas mesmas condições do de Emilinha Borba em Garotas e samba. O original com "Pedalando" está no documentário Assim era a Atlântida, de 1974. Adelaide nos relatou o processo de escolha da canção por ela interpretada. Segundo o relato da cantora, o diretor do filme, Watson Macedo, pediu que ela encontrasse uma música para fazer parte do filme. Em um dos dias de filmagem, ao chegar aos estúdios da Atlântida, Macedo ouviu o pianista Bené Nunes tocando uma melodia que acabara de compor em parceria com Anselmo Duarte. Macedo perguntou ao pianista se havia algum lugar da letra que ele pudesse encaixar a palavra Holanda, pois pretendia fazer para Adelaide participação no filme ambientado na Holanda. Anselmo e Bené adaptaram a letra, e a canção foi utilizada de maneira que podemos relacionar com as fantasias do Teatro de revista. 
Um ano após Carnaval no fogo, Adelaide participou de Aviso aos navegantes (1950). Aí ela teve seu nome, pela segunda vez, creditado como atriz. No ano anterior, Adelaide conquistara reconhecimento popular na carreira de cantora. Havia gravado "Beijinho doce", que, certamente, foi incluída na trilha musical para atrair o público que admirava a cantora. Na produção Adelaide atua como coadjuvante, mas participa de três números musicais, dois com Eliana Macedo, com as canções "Beijinho doce", de Nhô Pai, e "Recruta biruta", do trio de compositores Antonio Almeida, Nássara e Alberto Ribeiro, e um como protagonista em Sereia de bordo, de Bené Nunes e José Carlos Burle. Embora ela tenha uma personagem no filme, essa personagem é Adelaide, uma cantora que retorna de uma turnê na argentina. Portanto, apesar de estar inserida em uma ficção, ela é uma personagem que existe fora das telas. Nenhum desses quadros agrega informação, nem conduz à progressão dramático-narrativa. São todos quadros de ruptura. "Beijinho doce" e "Recruta biruta" pertencem a shows dentro do navio e "Sereia de bordo" é executada no convés do navio para um grupo de jovens passageiros. Um procedimento importante sobre a gravação de "Beijinho doce" nos foi informado por Adelaide Chiozzo. Ela nos relatou que houve, então, a captação de som direto. Como Eliana Macedo não era musicista e não sabia tocar nenhum instrumento, Carlos Matos, violonista, maestro e marido de Adelaide, teria ensinado a Eliana como deveria mover os dedos no braço do violão, enquanto Carlos executava a canção fora do enquadramento da câmera. Adelaide também nos informou que cantava a segunda voz e tocava acordeom e que, apesar da gravação em disco ter Adelaide na primeira voz, para o filme foi necessário que Adelaide fizesse a segunda voz, pois Eliana não conseguia manter-se afinada na segunda voz para a gravação com som direto.

Em 1951, em Aí vem o barão, a participação de Adelaide segue como no filme anterior, isto é, ela atua em números musicais, que trazem para as telas as canções consagradas em sua própria voz, como "Sabiá lá na gaiola", de Hervê Cordovil e Mario Vieira. A diferença é que pela primeira vez ela forma um dos pares românticos da comédia com Ivon Cury.

Em Barnabé tu és meu (1952) existem dois pares românticos. Antonieta (Adelaide) e Barnabé (Oscarito) formam o casal ameaçado de separação pela princesa 
que confunde Barnabé com um príncipe, com o qual deseja se casar. Como os rostos já eram conhecidos do grande público, não era mais necessário manter o nome do cantor; era possível assumi-los como personagens. Nessa comédia Adelaide canta “Lá vem o seu Tenório" de autoria de Manoel Pinto e Airão que é utilizada para apresentar a personagem de Adelaide e indicar a relação com a personagem de Oscarito.

Em 1954, Adelaide participou do filme Malandros em quarta dimensão. Em 1955 atuou em Guerra ao samba. Ainda não tivemos acesso aos filmes por falta de cópia para pesquisa, pois o arquivo da Atlântida passou, na década de 1970, por uma inundação e os filmes se encontram em tal estado de fragilidade que é impossível assisti-los.

A última produção em que Adelaide atuou na Atlântida foi Garotas $e$ samba (1957). Nele Adelaide foi protagonista e formou o principal par romântico com o cantor Francisco Carlos. Adelaide, segundo Carlos Manga, tinha uma carreira promissora, mas encerrou sua participação na Atlântida prematuramente, pois durante as filmagens de Garotas e Samba, o marido de Adelaide, Carlos Matos, causou confusões dentro dos estúdios, porque não aceitava que a esposa fizesse cenas de beijo. A cena final estava escrita com um beijo do par romântico, que acabou acontecendo, contudo Manga não a escalou mais para as produções que dirigiu. Em Garotas e samba, Adelaide cantou "Trenzinho do amor", de Silvan Castelo Neto e Lita Rodrigues, empregado para apresentar as habilidades da personagem como musicista, “Nossa Toada”, de Carlos Matos e Luiz Carlos e “Didi, Zizi, Naná", de Billy Blanco, que encerra a comédia e tem na letra um resumo de toda a história. É pertinente citar aqui a proximidade do número musical com os produzidos por Hollywood, devido à busca constante do diretor Carlos Manga de uma aproximação com o produto que ele considerava concorrente direto do produto brasileiro. Manga consolida uma transformação que já está em curso, afastando a inserção de canções dos filmes da Atlântida das práticas do teatro de revista e aproximando-os das convenções do filme musical norte-americano.

Embora Manga não tenha voltado a escalar Adelaide para as comédias da Atlântida, a cantora/atriz fez muitas outras comédias em outras companhias e 
conseguiu levar seu trabalho para as telenovelas, depois da invasão da televisão no Brasil, que contribuiu para uma queda nas produções de cinema no país. Adelaide participou de Feijão maravilha (1979), Deus nos acuda (1992), da Rede Globo de Televisão, e Uma rosa com amor (2010), do SBT.

\section{Dóris Monteiro nas produções da Atlântida}

A participação de Dóris na Atlântida foi pequena, se a compararmos com as das outras cantoras já mencionadas. Ela participou do filme De vento em popa (1957), dirigido por Carlos Manga, cuja trilha musical é uma das mais bem produzidas pela Atlântida. O mote da comédia é disparado por meio de uma confusão envolvendo músicos e shows. As duas personagens que formam o par romântico e a vilã são apresentadas por meio de inserções musicais, que também estabelece o mundo dos jovens, representado pelo rock, dos velhos, pela ópera, e dos cômicos, pela música popular brasileira.

Muitas informações são adicionadas à narrativa por números musicais nessa comédia. Uma delas é a capacidade dos cômicos em atuar como cantores e atores, fato que os coloca na função de cúmplices dos planos do par romântico, tal como acontecia com os zanni na Comedia Dell'Arte ${ }^{\mathbf{1 0}}$. Os cômicos participam de três números musicais. O primeiro com "O delegado no coco", de José de Souza Dantas Filho, e revela a capacidade de Chico (Oscarito) e Mara (Sonia Mamed) como artistas. O segundo reafirma essa condição depois de um grande tumulto que põe em risco os

\footnotetext{
${ }^{10}$ Espécie de representação profissional com propósito lucrativo, que teve início na Itália do século XVI. Esse gênero, em sua forma estabelecida, era composto por representação, canto, danças, exibições de habilidades e acrobacias. Existia, nas companhias, a figura do capocomico responsável pelo "arcabouço dramatúrgico" que envolvia no máximo de dez a doze pessoas. A formação mais comum contava com dois ou quatro namorados, dois velhos e dois criados. Os atores mascarados satirizavam os principais componentes da sociedade italiana da época. Os velhos eram pessoas avarentas, desconfiadas, apareciam comumente como dotore, jurista ou médico erudito e pedante, e pantalone, homem rico e de prestígio. A função dessas personagens era impedir os apaixonados de conseguirem o final feliz. Os chamados zanni eram criados, sempre estavam em dupla no palco a fim de criar os extremos entre o criado esperto, briguella, e o criado bobo, arlequim e assumiam a parte cômica da representação. Na versão feminina, zagna, as criadas recebiam o nome de Francesquina ou alguma variação próxima e nunca usavam máscaras. Os criados tinham a missão de burlar as ordens dos velhos e ajudar os jovens na batalha contra todos que desejassem impedir o amor de triunfar (SCALA, 2003, p. 15 a 37).
} 
planos do par romântico. A canção foi “Tem que rebolar", de José Batista M. de Oliveira. A última participação dos cômicos fecha o filme com "Calypso rock", de Carlos Eduardo Corte Imperial11 e Roberto Reis e Silva, quando os cômicos salvam o par romântico das investidas dos vilões.

Dóris Monteiro também interpreta três composições nessa comédia, mas o que podemos citar como mais importante é que elas formam uma linha de transformação da personagem no decorrer do filme. A personagem de Dóris, Lucia, é uma rica e tradicional herdeira que tenta conquistar o coração de um rapaz que acaba de chegar dos Estados Unidos, onde estudou música e produção de shows. Lucia é apresentada ao público durante uma aula de música erudita. Ela é orientada por Mara a mudar de estilo para ajudar nos planos de Sergio (Cyl Farney) e assim conquistá-lo. A tentativa vem com a canção "Chove lá fora" de Tito Madi, quando Lucia se mostra apta a cantar composições populares, como gosta Sergio. A canção "Do, ré, mi", de Fernando César, que teve arranjo de Tom Jobim, faz parte da cena em que Lucia conquista Sergio. "Mocinho bonito", de Billy Blanco, aparece na inauguração da boate de Sergio, quando o par romântico se apresenta junto.

Dóris Monteiro foi uma das poucas rainhas do rádio que fez a transição entre a interpretação de samba-canção e a de bossa nova. Segundo Billy Blanco12, amigo de Dóris, ele teria alertado a cantora para que modificasse sua maneira de interpretar as canções ou perderia espaço na mídia, pois previa a aproximação de mudanças significativas no panorama musical brasileiro.

A participação de Dóris Monteiro no filme ... E o espetáculo continua! (1958) pode ser comprovada pelo cartaz de divulgação, nos arquivos da Cinemateca Brasileira e por uma fotografia que pertencia ao material de divulgação do filme em vitrines, nas paredes externas das salas de cinema.

\footnotetext{
11 Apontamos aqui procedimento comum nos filmes da Atlântida. O citado Carlos Eduardo Corte Imperial era conhecido por Carlos Imperial, mas os créditos não acompanhavam os nomes artísticos dos envolvidos em qualquer uma das áreas da produção dos filmes. Podemos encontrar nomes cuja a grafia muda de uma para produção para a outra, como, por exemplo, o compositor Peterpan, que nos créditos de alguns filmes teve a grafia Peter Pan. Outro exemplo é o compositor Billy Blanco, que teve o seu nome - Willian Abrunhosa Blanco - nos créditos das primeiras produções com canções, de sua autoria que figuravam na trilha musical.

12 As informações de Billy Blanco para esta pesquisa foram obtidas em entrevista concedida em 2010.
} 


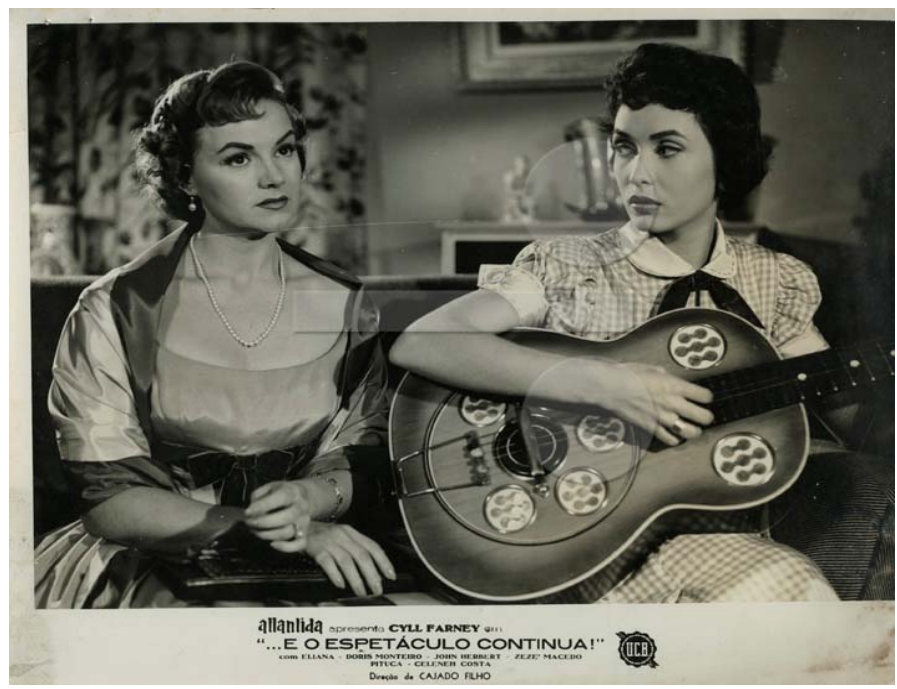

Figura $\mathrm{n}^{\mathrm{o}} 1$ - Material de divulgação do filme ... E o espetáculo continua!

Por falta de cópias para esta pesquisa devido à extrema fragilidade do original, não é possível descrever o tipo de participação de Dóris nesse filme. Mas, pela fotografia, podemos supor que a cantora Dóris Monteiro fez participações musicais nele.

\section{Francisco Carlos nas produções da Atlântida}

Nem só de rainhas viveu o rádio brasileiro na década de 1950. Muitos cantores foram considerados reis, como o caso do "rei da voz" Francisco Alves. Essas designações eram atribuídas em programadas de rádio, muitas vezes criadas pelos locutores, e eram consagradas pelos fãs.

A participação dos reis do rádio nos filmes da Atlântida não aconteceu com a mesma intensidade que a das rainhas do rádio. Existem diversas explicações para esse fato. Primeiramente pela presença de Oscarito. O diretor Carlos Manga considera que a Atlântida tenha tido dois símbolos: o chafariz, que abria os filmes, e Oscarito. A participação do cômico era tão forte que deixou em segundo plano os atores que representavam a figura masculina do par romântico. Outro fator importante é que os galãs da Atlântida (Anselmo Duarte, John Herbert e Cyl Farney) afirmaram-se como atores que não cantavam e o público aceitava que apenas a figura feminina das comédias realizasse essa função. Um terceiro fator era a diferença entre 
o apelo popular nos concursos de rei e rainha do rádio, já que as rainhas começaram a ser eleitas pelo público em 1948, enquanto que os concursos masculinos só iniciaram no fim da década de 1950.

Francisco Carlos foi eleito o primeiro rei do rádio em 1958. Ele teve seu primeiro disco gravado em 1950 pela RCA Victor. Nesse 78 rpm estava a marcha carnavalesca "Meu brotinho", e por causa dessa canção ficou conhecido por El Broto. Ela foi lançada no primeiro trabalho de Francisco Carlos para a Atlântida, Carnaval no fogo (1949). Encontramos aqui um exemplo claro de como funcionava o mercado fonográfico na época. A composição só foi gravada em disco meses após o seu lançamento no filme e sua aceitação por parte do público. A inserção de "Meu brotinho" interrompe a progressão dramático-narrativa e é justificado por um show no hotel onde se desenvolve a trama e pode ser encontrada aos 18 minutos do filme, mas não acrescenta elementos à narrativa.

Até o momento esta pesquisa confirmou a presença de Francisco Carlos nos seguintes filmes da Companhia Atlântida: Carnaval no fogo (1949), Aviso aos navegantes (1950), Carnaval Atlântida (1953), Guerra ao samba (1955), Colégio de brotos (1956), Garotas e samba (1957) e Esse milhão é meu (1958).

Em Aviso aos navegantes, Francisco Carlos está em dois números musicais. O primeiro com "Não vivo bem”, de Haroldo Lobo, Milton de Oliveira e Jorge Gonçalves, faz parte de um show dentro do navio onde viajam as personagens. $\mathrm{O}$ segundo é baseado na apoteose do Teatro de revista. “O tema da apoteose não tinha nada a ver com o restante da revista" (VENEZIANO, 1991, p. 111). “Durante muito tempo, este quadro final teve conotação de exaltação patriótica", e "eram as riquezas do Brasil que mais frequentemente forneciam o tema das apoteoses". Cantavam-se as belezas do Brasil, suas pedras preciosas, as personalidades ou heróis, ou até mesmo algum grande invento recente (VENEZIANO, 1991, p. 110-1).

A referida apoteose ao Rio de Janeiro contida em Aviso aos navegantes acontece no último do show do navio, antes da chegada do navio à cidade; o cantor principal é Francisco Carlos, em "Rio de Janeiro", de Ary Barroso. O cenário é a "cidade maravilhosa", entretanto dentro do salão de bailes do navio. Na presença de muitas bailarinas, Eliana e Oscarito dançam ao som do samba-exaltação. Anselmo 
Duarte, que faz par romântico com Eliana, entra no palco ao fim da canção para o esperado beijo. Oscarito fecha, literalmente, a cortina. "Rio de Janeiro" não era um lançamento, a gravação era vendida desde 1950.

No filme Carnaval Atlântida, Francisco Carlos canta "Quem dá aos pobres" de autoria de Armando Cavalcanti e Klecius Caldas em um ensaio para a gravação de um filme, dentro de outro filme. Como os números musicais precisavam, na opinião dos diretores, ser justificados, ocorreram várias inserções nesse modelo (um ensaio para alguma apresentação cultural). Cabe aqui uma reflexão sobre os procedimentos adotados pelos diretores da Atlântida. Eles defendiam a proximidade com os filmes norte-americanos, acreditavam na necessidade de certas convenções, como a justificativa do elemento música, mas não eram tão fiéis assim a tais procedimentos, de maneira que foram estabelecidas convenções brasileiras para a trilha musical produzida no país.

A participação de Francisco Carlos em Guerra ao samba (1955) só pode ser comprovada pelo cartaz do filme. ${ }^{13}$ Já em Colégio de brotos, Francisco Carlos é o protagonista. A narrativa ocorre em uma escola, e Francisco é Flávio, um estudante que tem planos de seguir a carreira de cantor. Existem cinco inserções de canções nessa produção. A primeira é a dos créditos, que se repete ao fim da narrativa e é o "Hino da escola". Encontramos nesse filme um caso raro no acervo da Atlântida. Com exceção do "Hino do colégio", todas as demais composições são interpretadas pelo mesmo cantor: Francisco Carlos. São elas: "Você não sabe amar", de Dorival Caymmi, "Flor", de Fausto Guimarães, "Minha prece”, de Haroldo Eiras e Ciro Vieira da Cunha, e o "Hino ao samba", de Henrique Delff. Todas as inserções adicionam elementos à narrativa que descreve os caminhos de Flávio até chegar ao sucesso como cantor.

Garotas e samba foi mencionado anteriormente, por ter sido protagonizado por Adelaide Chiozzo. Vale citar que o par romântico foi composto por dois cantores e não por uma mistura entre atores e cantores como ocorria frequentemente na Atlântida. Nesse filme Francisco Carlos interpreta “Quem vai gargalhar”, de Domicio

\footnotetext{
${ }_{13} \mathrm{O}$ original está na lista de espera por digitalização para criar cópia para pesquisa, até que isso aconteça, é impossível assistir ao filme pelo estado de fragilidade em que este se encontra.
} 
Costa, José Roy e Luiz Bel. O número musical com esta canção apresenta a personagem Sergio Carlos (Francisco Carlos), um famoso cantor do rádio por quem Didi (Adelaide Chiozzo) se apaixona.

A última participação de Francisco Carlos na Atlântida também foi como protagonista e integrante do par romântico. Em Esse milhão é meu (1958) ele interpreta "Ladeira do amor", de João Batista da Graça e Amado Soares dos Regis, e "Flor amorosa", de Joaquim Antonio da Silva Calado com letra de Catulo da Paixão Cearense. Todas agregam elementos novos à narrativa. Por sinal, a composição que introduz a personagem de Francisco Carlos é uma das raras inserções de canções em cenas externas.

\section{Considerações finais}

Os filmes musicais da Companhia Atlântida Cinematográfica apresentam um grande número de canções em suas trilhas musicais. Embora sua referência fosse o cinema norte-americano, principalmente os filmes musicais, a escolha e a utilização desse tipo de composição se deram muito mais por influência do Teatro de Revista, do rádio popular e das festas populares do que dos musicais de Hollywood. Porém, com a troca de diretores, aporte tecnológico e amadurecimento profissional dentro da empresa, as produções foram aproximando essa produção brasileira dos procedimentos do cinema norte-americano no que diz respeito à articulação das canções nos filmes, assim como suas relações dramático-narrativas.

Tais relações, no filme musical brasileiro, foram de condução, de adição de elementos ou de ruptura. O musical da Atlântida raramente utilizou a letra da canção para conduzir a narrativa em substituição ao diálogo. As inserções aconteceram com maior frequência na forma de rompimento da narrativa. Sob esse aspecto pode ser notada a influência do mercado fonográfico, da indústria cultural e do gosto do público, que demandava a necessidade de conhecer os rostos dos cantores do rádio já consagrados pela voz. O público aceitou as convenções poéticas do musical brasileiro e tornou-se frequentador assíduo das salas de cinema quando a projeção era de filmes musicais produzidos pela Atlântida. 
Nas décadas de 1940 e 1950, no Brasil, não havia uma escola de formação de profissionais de cinema. Os envolvidos no processo cinematográfico aprendiam a desenvolver suas funções pelo método que em inglês é chamado de training on the job, ou seja, o profissional aprende trabalhando junto com profissionais mais experientes na própria companhia. Era necessário adequar-se ao material e à tecnologia disponível. Desse modo, houve um facilitador entre a presença dos cantores/atores e a necessidade dos diretores de justificar, da melhor maneira possível, a presença de tantas canções em um só filme. Portanto, o fato das rainhas e reis do rádio, assim como outros cantores, terem protagonizado filmes na Atlântida não se deve apenas à influência da indústria cultural. A pouca oferta de atores habilitados a cantar, no mercado dramático brasileiro, criou uma situação em que ou se ensinava os atores a cantar ou os cantores a representar. Por razões já expostas, optou-se pela segunda alternativa. Se eles precisavam de música, era totalmente compreensível que considerassem a hipótese de trabalhar com quem cantasse bem.

Por fim, afirmamos que os filmes da Atlântida, além de formarem um acervo de grande importância na história do cinema brasileiro, são portadores de registros audiovisuais ímpares e, por esse motivo, são extremamente importantes para as pesquisas em música e em cinema. Daí a necessidade imperiosa da restauração dos filmes produzidos pela Atlântida, antes que se percam totalmente esses registros tão preciosos da história da arte popular brasileira.

\section{Referências bibliográficas}

BARRO, Máximo. José Carlos Burle: drama na chanchada. São Paulo: Imprensa Oficial, 2007.

CALABRE, Lia. A era do rádio. Rio de Janeiro: Jorge Zahar Editor, 2002.

CARRASCO, Claudiney Rodrigues. Trilha musical: música e articulação fílmica. Dissertação (Mestrado). Escola de Comunicações e Artes, Universidade de São Paulo, São Paulo, 1993.

HUPFER, Maria Luisa Rinaldi. As Rainhas do Rádio. Rio de Janeiro: Senac, 2009. 
RAMOS, Fernão e MIRANDA, Luiz Felipe. Enciclopédia do cinema brasileiro. São Paulo: Senac, 2004.

SCALA, Flaminio. A loucura de Isabella e outras comédias da Commedia Dell'Arte. São Paulo: Iluminuras, 2003.

SEVERIANO, Jairo e MELLO, ZUZA, Homem de. A canção no tempo - vol. 1: 1901 1957. São Paulo: Editora 34, 1997.

VENEZIANO, Neyde. O teatro de revista no Brasil. Campinas: Editora da Universidade Estadual de Campinas - UNICAMP, 1991. 